\title{
Improving leadership and management education in medical school
}

This article was published in the following Dove Press journal: Advances in Medical Education and Practice

\section{Ravina Bhanot}

Barts and The London School of Medicine and Dentistry, Queen Mary University of London, London, UK
Correspondence: Ravina Bhanot Faculty of Medicine, Barts and The London School of Medicine, 4 Newark Street, Whitechapel, EI 2AT London, UK Email r.bhanot@smdI3.qmul.ac.uk

\section{Dear editor}

The article by Rouhani et al ${ }^{1}$ regarding medical students' perception and attitude toward medical leadership brings great interest. Alongside clinical competency, a doctor must also be able to communicate as a leader ${ }^{2}$ and negotiate and use resources efficiently in an over-stretched National Healthcare Service (NHS). As an ambassador of the Faculty of Medical Leadership and Management (FMLM) and having completed an intercalated degree in health care management, I write to share my experiences and propose implementation methods of medical leadership into the curriculum.

The authors suggest that there is an appetite for management training, yet the quality of training supplied by UK medical schools is limited. ${ }^{1}$ Barts and The London launched the first UK MedTech and leadership module, "Barts X Medicine", for medical students in 2017. The weekly lecture day consisted of students learning about leadership and entrepreneurship and bringing innovative solutions to solve NHS problems. The pilot module was well received and will now be rolled out to all students within this university. Essential tools required by clinical managers can be taught in a lecture and workshop-based module of this nature. Discussing case studies of hospital management strategies enables clinical relevance to be brought to a management module, for example, an analysis of the Keogh Mortality Review or the pitfalls discussed in the Francis Report. Negotiation sessions can teach students how to communicate their view point and overcome obstacles as a multidisciplinary team. Currently, the FMLM is undertaking curriculum analysis research to identify areas where health care leadership teaching can be provided. Coding each UK medical school timetable will highlight where education can be integrated into the syllabus, without jeopardizing other educational priorities.

Another finding of the article indicates that a majority of the students possess interest in management roles. ${ }^{1}$ Leadership has been shown to have positive association with clinical outcomes in health care. ${ }^{3}$ However, from my experience, there is little awareness on the leadership opportunities available. Advocating medical management student selected components, electives, and postgraduate clinical leadership fellowships can allow students to gain exposure through other educational methods. Raising awareness on the importance of managerial education can be signposted by universities. Leadership learning objectives can be achieved by reflective writing assessments on health management scenarios, inclusion of observed leadership skills in the logbook, and increased provision of audits or quality improvement projects. 
Incorporation of medical management into the curriculum could equip medical students to improve the future health care service. Before structural reorganization of the medical school curriculum, rigorous research is required to compare whether provision of health management education in university produces effective clinician managers.

\section{Disclosure}

The author reports no conflicts of interest in this communication.

\section{References}

1. Rouhani M, Burleigh E, Hobbis C, et al. UK medical students' perceptions, attitudes, and interest toward medical leadership and clinician managers. Adv Med Educ Prac. 2018;9:119-124.

2. General Medical Council. Leadership and management for all doctors [Internet]. Manchester; 2012 Jan p. 8. Available from: https://www.gmcuk.org/-/media/documents/Leadership_and_management_for_all_doctors_English_1015.pdf_48903400.pdf. Accessed April 24, 2018.

3. West M, Armit K, Eckert R, West T, Lee A. Leadership and Leadership Development in Health Care: The Evidence Base [Internet]. London: Faculty of Medical Leadership and Management; 2015:2-4. Available from: https://www.kingsfund.org.uk/sites/default/files/field/field_publication_file/leadership-leadership-development-health-care-feb-2015. pdf. Accessed April 24, 2018.

Dove Medical Press encourages responsible, free and frank academic debate. The content of the Advances in Medical Education and Practice 'letters to the editor' section does not necessarily represent the views of Dove Medical Press, its officers, agents, employees, related entities or the Advances in Medical Education and Practice editors. While all reasonable steps have been taken to confirm the content of each letter, Dove Medical Press accepts no liability in respect of the content of any letter, nor is it responsible for the content and accuracy of any letter to the editor.

\section{Publish your work in this journal}

Advances in Medical Education and Practice is an international, peerreviewed, open access journal that aims to present and publish research on Medical Education covering medical, dental, nursing and allied health care professional education. The journal covers undergraduate education, postgraduate training and continuing medical education including emerging trends and innovative models linking education, research, and health care services. The manuscript management system is completely online and includes a very quick and fair peer-review system. Visit http://www.dovepress.com/testimonials.php to read real quotes from published authors.

Submit your manuscript here: http://www.dovepress.com/advances-in-medical-education-and-practice-journal 